\title{
Undifferentiated Pleomorphic Sarcoma
}

National Cancer Institute

\section{Source}

National Cancer Institute. Undifferentiated Pleomorphic Sarcoma. NCI Thesaurus. Code C4247.

An undifferentiated soft tissue sarcoma characterized by the presence of a pleomorphic malignant cellular infiltrate. It is also known as malignant fibrous histiocytoma. 